\title{
THE PROBLEMATIC REPRESENTATIONS OF THE ORIENT, WOMEN, AND FOOD TRANSFORMATIONS IN PAOLO BACIGALUPI'S THE WINDUP GIRL
}

\author{
Jungyoun Kim \\ Sungkyunkwan University \\ remedios56@naver.com
}

\begin{abstract}
Paolo Bacigalupi's novel, The Windup Girl, illustrates Bangkok using genetic diseases and plagues. In this work, mass-produced, genetically modified food becomes both a diplomatic weapon and subsistence for survival. Western-based multinational agri-corporations transform food as industrial products, and Bacigalupi in turn illustrates the problems of genetic modification led by global capitalism and multinational corporations. However, his critique of genetic modification and food transformation relies on ethnic and gender stereotyping within an Orientalist frame. While he challenges the practices of corporate capitalism, his representation of Asian cultures and traditions is monolithic and consistently reproductive of Orientalist stereotypes. Also, the politics of representation in the novel is closely related with identity politics and subjectivity. In particular, the politics of representation in Bacigalupi's novel are suspect in constructing Orientalist and sexist stereotypes as a frame, making his critiques of genetic modification and food transformation within Western power structures questionable.
\end{abstract}

\section{Keywords}

ecofeminism; food transformation; Orientalism; GMO; representation; Western hegemony

\section{About the Author}

Jungyoun Kim is a lecturer of English Literature and Translation Studies at Sungkyunkwan University, Seoul, Korea. She received her MA in Translation Studies and PhD in English Literature in 2016 from Sungkyunkwan University. Her research interests include Victorian and Neo-Victorian novels in relation to psychoanalytic criticism and cultural studies, as well as Victorian literature in the context of ecocriticism. She has published several articles in both international literary journals and Korean journals. She is currently working on a book project that explores Victorian literature and ecocriticism. 
Paolo Bacigalupi's dystopian biopunk novel The Windup Girl portrays a world that has collapsed because of genetic diseases and plagues, a world in which massproduced, genetically modified food has become both a diplomatic weapon and survival sustenance. The foods in $23^{\text {rd }}$ century Bangkok are controlled by Westernbased multinational agri-corporations and are transformed as industrial products that make profitfor corporations. Interestingly, what most people from industrialized countries buy to eat today is very similar to the foods depicted in the novel: processed, packaged, stamped, and labeled. Bacigalupi illustrates the problems of genetic modification led by global capitalism and multinational corporations; however, his critique of genetic modification and food transformation also relies on ethnic and gender stereotypes that construct Asia and its women as Other. While the novel challenges the practices of corporate capitalism, its representation of Asian cultures and traditions is monolithic and reproduces stereotypes of the Orient. The dangerous and uncertain future of food transformations, moreover, is entangled with racial and gender matters in the novel. In this paper, I argue that the politics of representation in Bacigalupi's novel are suspect in their construction of Orientalist and sexist stereotypes as a frame; therefore, this, in some ways, compromises the novel's critiques of genetic modification and food transformations.

The Windup Girl reveals a world where the transformation of food into an economic weapon is remarkable. In a discussion about food as commodity, Scott Selisker remarks that "as with Marx's commodity, wherein the surface of the product we see occludes the labor relations that went into its manufacture, the GMO can appear on a plate or in a grocery store without betraying its origins" (504). The foods in Bacigalupi's Bangkok are controlled by Western-based multinational corporations and are transformed into industrial products and commodities. Their sole purpose is to make profit for the multinational corporations such as AgriGen, HiGro, UTex, and PurCal, all of which are reminiscent of Monsanto, the presentday multinational agricultural biotechnology company headquartered in Missouri. The companies in The Windup Girl produce genetically modified food products and even human beings, thereby distributing these dangers worldwide. GMOs are indeed a dangerous business. Timothy Morton argues that "what's wrong about genetic engineering is that it turns life forms into private property to enrich huge corporations" (86). In Bacigalupi's $23^{\text {rd }}$ century Bangkok, food, plants, and animals are the products of corporate-led genetic modification. One example is the phenomenon of roaming Cheshire cats in every alley of the city. According to Bacigalupi's novel, they were "supposedly created by a calorie executive some PurCal or AgriGen man, most likely" (26); still, "somewhere in this city a generipper is busily toying with the building blocks of life. Reengineering longextinct DNA to fit post-Contraction circumstances, to survive despite the assaults of blister rust, Nippon genehack weevil and cibiscosis" (64). Genetic mutation and 
subsequent diseases caused by agri-companies have thus become possible dangers that Bangkok faces in the novel.

It is a matter of fact that genetically modified organisms posit dangers. With GMO foods, it is not always possible to know what is inside the food, and this is an infringement of consumer rights to make educated choices. Furthermore, "GM plants are virtually everywhere in the US food chain, but don't have to be labeled, and aren't. Industry lobbyists intend to keep it that way" (Kingsolver 52). The foods that Thais eat in The Windup Girl are something to be suspicious of, as they are "unnatural," are potential disease carriers, and inaccessible without corporate manipulation. In the novel, the Thais are narrated as "eating a steaming bowl of U-Tex rice porridge with small bits of unidentifiable meat buried in the paste" (73). The example of U-Tex comprises food products that do not reveal their origins, and in relation to this, multinational corporations hold the means for people to acquire and consume such food. After all, they also control production and distribution of foods. Pointing out the increasing domination of agri-corporations in seed sales, Barbara Kingsolver notes that today,

Six companies - Monsanto, Syngenta, DuPont, Mitsui, Aventis, and Dow - now control 98 percent of the world's seed sales. These companies invest heavily in research whose purpose is to increase food production capacity only in ways that can be controlled strictly. (51)

Instead of informing people of the origins and genetic sources, the food products from the corporations usually have stamps and labels that guarantee the safety with very clean, pretty, and colorful appearances-as pretty and smooth as the windup girl Emiko in the novel.

A lot of what people buy to eat today in industrialized countries is heavily processed, packaged, stamped, and labeled. It looks clean, pretty, and safe, devoid of any trace of butchering or death. It no longer bears traces of the fact that it is a part of a dead animal's carcass. Carol Adams argues that "through butchering, animals become absent referents. Animals in name and body are made absent as animals for meat to exist" (66). Meat does not seem to be from animals that were once alive. Meat bears different signifiers, such as beef, steak, pork, veal, and lamb chops. Such terms conceal the past lives of the flesh on the plate, obscuring their origins. Animals are transformed into food products, consumer goods, commodities, and profit. Today, people go to a supermarket (or to McDonald's) for food and end up with packaged products of substantially transformed materials. These substances are often labeled with guarantees of safety and inspection. Labeling itself obscures the degree of transformation in the substances we eat. Win Welford, who scrutinizes the politics behind food labeling in his article "Supermarket 
Semantics: The Rhetoric of Food Labeling and Advertising," observes that "the matter of buying well (in terms of health) is clouded ... by multi-million dollar labeling and advertising campaigns. Most consumers are perplexed about how to interpret these ads and labels" (4). Labels take center stage in The Windup Girl, as becomes very clear with the fruit called Ngaw.

Anderson Lake, who is secretly looking for a new seed in Thailand for his company AgriGen, finds the strange fruit called Ngaw, from which he wants to profit. When he shows the Ngaws to other business people and tells them that "'the lady who sold them said they were clean. Had the certificates[,]' Everyone laughs" (89). The signs that are supposed to guarantee the safety have become a laughable joke: "the intricate stamps that glitter in the sun are more talismanic than functional, something to make people feel secure in a dangerous world. In truth, if cibiscosis breaks out again, these certificates will do nothing" (3). The recent egg contamination scandal in 2017 that started in Europe and spread around the world shows precisely that "guaranteed safety" of mass-produced food is a problem. Bacigalupi portrays Bangkok as a city that narrowly escaped the diseases that scourged the rest of the world and that this is owing to the secured seedbank, a source of mysterious Oriental fecundity; yet the food and the lives of people are under a constant threat despite the efforts of the government and the military to shield their country from Western-based multinational agri-companies.

Food is a central issue of geopolitical power. In South Korea, where I live, this centrality is particularly visible. In 2008, we experienced widespread fear over meat imported from the USA that was supposedly disease-infected, and despite denials from both the US government and the American cattle industry who denounced protesters "as irrational and ignorant of science, while defending the safety of American beef" (Kang 587), South Koreans were defiantly suspicious of any government-issued certificates and safety-guarantee papers. To this day, many Koreans still refuse or are hesitant to buy or eat US-produced beef; in fact, the matter has become one of the central diplomatic issues between the US and South Korea. This also reflects the hierarchy of power between the two countries, since the South Korean government was aware of public outrage but did not stand up against the US government and the meat industry lobbyists. Tainted meat, however, is only the tip of the iceberg: GMOs are an even more volatile topic.

Bacigalupi criticizes genetic modifications that can alter geological and ecological landscapes. The Windup Girl is concerned with ethical outcomes, a topic that reaches its climax through Emiko, a genetically engineered human being. Andrew Hageman, noting the author's restructuring of the future in his article "The Windup Girl and the Challenges of Imagining Ecological Future," points out that "Bacigalupi remaps global capitalist geopolitics, interrogates the 
future of the nation-state in the face of transnational corporations, and explores the dynamics between capitalist commerce and ecological sustainability" (284); however, the politics of representation regarding the windup girl Emiko in relation to genetic modification has three important implications: firstly, Bacigalupi's use of an "exotic" setting discloses the Orientalist perspective; secondly, a particular Asian tradition, that of the geisha, is appropriated in the image of the windup girl, revealing Western fantasies of Asian women, as I will illustrate shortly; and thirdly, Bacigalupi's representation of food transformation within this Orientalist and sexist frame is not only rooted in Western hegemony but also solidifies this cultural colonialism. The Windup Girl demonstrates the dangers of processed, genetically engineered, and labeled foods: it foregrounds the problems of food transformation. Bangkok, the city in which Emiko struggles to survive, is based on the stereotypical and Orientalist image of the city's present: it is exotic, inscrutable, enigmatic, and malicious, and it is a spatial/geo-political object of "discovery," hiding priceless secrets such as Emiko herself. Bacigalupi acknowledges that "while this book is set in a future version of Thailand ... [it] should not be construed as representative of present-day Thailand or the Thai People" and that he is "solely responsible for its errors, omissions and transgressions" (361). Still, these comments do not, cannot, and should not obscure the fact that the novel's representations of $23^{\text {rd }}$ century Thailand are rooted in the realities of present-day Thailand. The country is, at present, a middle power in the Southeast Asia with a rapidly industrializing economy. It is a popular destination for tourism, and Bangkok is the most populated city of the country-a country known for political and social corruption, military coups, sex tourism, and prostitution. ${ }^{1}$ In addition to this social corruption, ecological problems are also mounting in Thailand. In Planet of Slums, Mike Davis describes Bangkok as a city whose residents "suffer from . . . 'garbage dump syndrome': a concentration of toxic industrial activities such as metal plating, dyeing, rendering, tanning, battery recycling, casting, vehicle repair, chemical manufacture, and so on, which middle classes would never tolerate in their own districts" (127). Meanwhile, Bacigalupi's future Bangkok, especially the factory district where Lake runs his factory, closely resembles present-day realities but with added rottenness and disease-infected food. The politics of representation here are at best questionable.

The representational maneuvers of The Windup Girl reveal "the essentialized conception of the East," making "Europe [West] and Asia appear to be fundamentally different from each other" (Pickering 148). The Thais possess strange and exotic foods that no other country has. According to Edward Said in his seminal work Orientalism, "Orientalism is a style of thought based upon an ontological and epistemological distinction made between 'the Orient' and 'the Occident'. . . [it is] a Western style for dominating, restructuring, and having authority over the Orient" $(2-3)$. Nonetheless, Said's study of Orientalism is much contested. ${ }^{2}$ Indeed, it does have some shortcomings of counter-essentializing the West, thus stereotyping the 
very structure that is guilty of stereotyping; however, Said's critique can be useful in scrutinizing The Windup Girl's narrative structure and its representation of genetic modification and food transformation.

Orientalism is a cultural representation of Western domination, and Bacigalupi's narrative follows the very steps that Said's "Orientalists" take, as the novel foregrounds the exoticism of Thailand and its seed bank. According to Said, "a certain freedom of intercourse was always the Westerner's privilege; because his was the stronger culture, he could penetrate, he could wrestle with, he could give shape and meaning to the great Asiatic mystery" (44). Moreover,

The Orient was overvalued for its pantheism, its spirituality, its stability, its longevity, its primitivity, and so forth. . . Yet almost without exception such over-esteem was followed by a counter-response: the Orient suddenly appeared lamentably underhumanized, anti-democratic, backward, barbaric, and so forth. (150)

In The Windup Girl, Thailand is the only country that has survived apocalyptic financial and biological disaster, thanks in large part to the embargo policy and highly secured seed bank, an enigmatic source of fecundity and vitality. It is Lake's job to penetrate into the seed bank and find out the secret of the life source:

Somewhere in this country a seedbank is hidden. Thousands, perhaps hundreds of thousands, of carefully preserved seeds, a treasure trove of biological diversity. Infinite chains of DNA, each with their own potential uses. And from this gold mine, the Thais are extracting answers to their knottiest challenges of survival. With access to the Thai seedbank, Des Moines could mine genetic code for generations, beat back plague mutations. Stay alive a little longer. $(86)^{3}$

In the novel, Lake is "just another grubby farang [foreigner] entrepreneur trying to make a buck along with jade prospectors and the clipper hands" (63). Bacigalupi seems to criticize the imperialist modes of colonization by foregrounding ethnic and racial chaos in his "exotic" setting, where global capitalists cannot wait to devour every remaining crop for profit, and where they transform every food to a commodity. However, the omniscient narrative mostly follows Lake's perspective and his judgment, which is decidedly Orientalist.

In contrast, Malisa Kurtz favors Bacigalupi's way of representing the racial and ethnical situation. Kurtz examines techno-Orientalism in her essay on The Windup Girl and argues that the novel "avoids constructing monolithic racial representations, taking into consideration the historical, political, social, and technological structures that influence how race is read and represented" (178). While Kurtz recognizes Bacigalupi's critique of "the rise of biotech companies and 
their increased control over worldwide food production and distribution" (178), it is nonetheless not clear exactly where she sees the author's avoidance of "monolithic racial representations." Indeed, his depictions of Thais, Chinese, and Japanese are consistently based on historically, politically, and socially prevalent Western's images of the Orient. The narrative writes Thailand as politically corrupt, sexually promiscuous, and entrepreneurially "incompetent" (14), while Thais "simply lack the spirit of entrepreneurship" (132). For Lake, "only Thais would spend so much time making a bribe look like a service agreement. They're polite, even when they're shaking you down" (15). While Kurtz does point out that "the stereotype of the 'lazy native' is a prejudice often rendered against native Thais" (183), she still remarks that,

Bacigalupi's frequent use of racially loaded language is not, however, in the tradition of ethnocentric colonial fiction. Rather, the emphasis on racial distrust and animosity highlights the growing divisions among peoples forced to survive under the conditions of a brutal capitalist economy. (183)

Unfortunately, this reading by Kurtz ignores the politics of representation. To illustrate, consider the difference between an African-American using the " $n$ " word and a white American senator using it. Bacigalupi is on thin ice, and what he emphasizes in actuality is not "racial distrust and animosity" but stereotypes of racial and ethnic prejudice. In Judith Butler's words, "representation is the normative function of a language which is said either to reveal or to distort what is assumed to be true" (2). Bacigalupi's language cannot be free from the politics of representation in spite of how ambitious his postcolonial intentions or his awareness about food transformations may be.

All around Lake, ethnically diverse groups of people interact with each other and fight for an advantageous position in the global food market, but they are portrayed through Lake's eyes and his words. Hock Seng, Lake's factory manager, is an archetypal sly, bony, and emasculated old Chinese man who is constantly fearful of his own shadow, due to the genocide he suffered in the Malay. As an ethnically despised refugee, Hock Seng is racially labelled "a yellow card," and "Anderson studies the yellow card . . trying to determine his honesty. . . it galls him that the old man thinks he can be fooled so easily" (16). Hock Seng is a cunning, asexual, typical caricature of a Chinese person. ${ }^{4}$ The novel's representation of Japanese culture is also stereotypical. The windup girl Emiko is a genetically modified "New Person," a new Japanese, like newly created genetically modified food. One of the executives of the Japanese manufacturer of the windups says, "New People value discipline. Order. Obedience. We have a saying in Japan, 'New People are more Japanese than the Japanese"' (300). That is, the windup girl has the quintessential characteristics of the Japanese and the traditional culture that the West generally

Kritika Kultura 33/34 (2019/2020): 571-583

(C) Ateneo de Manila University

<http://journals.ateneo.edu/ojs/kk/> 
associate with Japan, and upon which Bacigalupi frames his representations of food transformations.

Lake meets Emiko while he struggles with the factory management and his secret pursuit of seeds. Emiko is genetically designed to help and pleasure Japanese businessmen: she is a "collection of cells and manipulated DNA - with its own stronger, practical needs" (34), a "personal secretary: translation, office management and ... companion" (113). She represents a genetically modified product. Like a GM seed, she is "optimally designed" (201) to contain necessary features, such as disease-resistant genes and a potentiality that can kill off whatever things that harm her, like a seed that contains pesticides. Emiko has been, however, abandoned in Bangkok by her former owner, and as a result "she had been trapped in this suffocating perfect skin by some irritating scientist with his test tubes and DNA confetti mixes who made her flesh so so smooth, her insides too too hot" (35 -6). Vulnerable to the heat and abandoned without any protection, she ends up in a sex club in a back alley of Bangkok, for which the city is well known:

New people serve and do not question. She moves toward the stage with the careful steps of a fine courtesan, stylized and deliberate movement, refined over decades to accommodate her genetic heritage, to emphasize her beauty and her difference. (36)

The windup girl's genetic ancestor can be identified with Japanese geisha, a highly refined traditional Japanese courtesan. She is genetically modified to be "born natural" as a geisha, just like an exotic delicacy of transformed food that is prepared for a Westerner.

As a popular American novelist, Bacigalupi chooses the easiest way to please his targeted readers by constructing an exotic and sexualized foreign tradition. The stereotypical image of the geisha is widely known in America, in part through Arthur Golden's 1997 bestseller novel Memoirs of a Geisha, which represents the geisha and its culture tailored to Western tastes. Professor Kimiko Akita at Aichi Prefectural University in Japan criticizes Golden and claims that his book "reinforced the Western stereotype of geisha as a promiscuous sexual object. Japan thereby was commodified as a Western object: a fiction of the West, by the West, and for the West - yet received by the West as non-fiction, or reality ... Golden reduced his geisha to an irrational, erotic Oriental woman" (15). Akita's critique of Golden and his narrative reification of "the Western stereotype of geisha as an exotic, erotic, submissive and beautiful creature/object" (15) can be applied to The Windup Girl; after all, the novel "maintain[s] patriarchal white supremacy and [carries] out [its] Orientalist project ... by portraying a geisha as an emotional and promiscuous creature" (Akita 15). The novel places Japanese geisha culture under the Western (certainly English-speaking) voyeuristic gaze. 
Traditional Japanese geisha culture involves complete obedience and entertainment through a sophisticated demeanor. When Kanya, a Thai military officer, meets Hiroko (another windup girl) for the first time, "she [thinks] she sees a little of what the Japanese desired from their engineered servants. The girl is perfect, precise as clockwork, and contextualized by the tea ceremony, all her motions take on a ritual grace" (297). In this way, Emiko also shows that genetic engineering can select the necessary characteristics with precision, as genetically modified food contains the engineered genes as desired. Hiroko remarks on the dependent and subordinate character of the windups, explaining that "it is in our genes. We seek to obey. To have others direct us.... We are more Japanese than even the Japanese. We must serve within a hierarchy" (302). Obedience and hierarchy seem to be marked as a most important trait of Japanese culture, as if the more a person is obedient, the more that person becomes Japanese. Yoko Kawaguchi comments in her book on geisha that in Western culture, "As a Japanese girl growing up in North America ... [she] used to be greatly irritated that the geisha appeared to be one of the chief images associated with Japan and its culture. That mincing, simpering personification of female subservience to the male infuriated [her]" (1). The windup is this personification taken to the level of genes, and Emiko is the human face of genetic manipulation. As such, she is a direct parallel of GM foods.

As a genetically modified geisha, Emiko conforms to the image of Golden's geisha, particularly as she embodies irrationality, promiscuity, and passivity. Engaged in sexual contact with another woman,

Emiko moans again as her body betray her. She cries out. Arches. Her body performs just as it was designed - just as the scientists with their test tubes intended. She cannot control it no matter how much she despises it. . . She comes. The audience roars approval, laughing at the bizarre conclusions that orgasm wrings from her DNA. (38)

On the stage of the sex club she is in, Emiko is sexually humiliated in front of the customers; however, this scene illustrates how Emiko's DNA, her "genetic heritage" of geisha (and, more specifically, Golden's version of geisha), hardwires her to a sexual indulgence that she herself cannot control. Lake also wonders at her sexuality: "Does she mean to encourage? Or is it simply her nature to entice? Perhaps she cannot help herself at all ... Is she even capable of refusing? .. . Did the geneticists embed her DNA with pheromones? Her body is intoxicating" (115-16). In other words, The Windup Girl portrays Japanese women as nymphomaniacal, and Emiko's gene is carefully selected to contain this quality. The novel thus constructs a sexual fantasy of an Oriental woman and compares Emiko's genetic modification with GM foods that contain certain ecologically strong and economically desirable genes. 
Emiko's "genetic heritage" is further emphasized with gender specificity as the novel uses male sexual fantasies of possession and rape, which corresponds with the discourse of racism, and meat consumption. Examining the correlation between meat eating and racism, Carol Adams argues that,

I mean racism as the requirement that power arrangements and customs that favor white people prevail, and that the acculturation of people of color to this standard includes the imposition of white habits of meat eating. (53)

Meat eating, according to Adams, endorses violence against animals, and "cultural images of sexual violence, and actual sexual violence, often rely on our knowledge of how animals are butchered and eaten" (68). The novel "associates the Orient with the escapism of sexual fantasy" (Said 190), as ". . . the Orient seems . . . to suggest not only fecundity but sexual promise (and threat), untiring sensuality, unlimited desire, deep generative energies" (188). Examining the male fantasies of possession and glorification of rape, Jane Ussher, in her book Fantasies of Femininity, explains that "representations of rape are invariably presented as seductions. . . . The woman raped is invariably ripe and ready, her assailant powerfully taking her as his rightful prize ... She is usually depicted as struggling, her attempted escape adding a sense of excitement and mastery to man's possession" (99-100). Similarly, colonized territories are geographies and cultures that are violated by the strong and aggressive West. Sara Suleri criticizes repetitive discourse of the rape metaphor in postcolonial rhetoric:

... the anxieties of empire are only obscured by a crucially unquestioning recuperation of the metaphor of rape, in which colonized territory is rendered dubiously coterminous with the stereotype of a precultural and female geography. The prevalence of this metaphor is evident in ... the colonization of the subcontinent in terms of stereotypical sexual aggression. (16-17)

Emiko represents the possession and rape of the Orient, and Lake's relationship with her is nothing other than a sexual fantasy of possession and rape. This metaphor imagines Asia and its culture as a feminine colonial object that can be violated. This representation bestializes the Orient as "under-humanized ... barbaric" (Said 150), and as irrational, sensual, and promiscuous. The Orient becomes an object ready to be consumed and to be treated as other-than-human. Emiko is like an animal that is ready to be butchered and consumed as an edible object.

The novel dehumanizes Emiko: she is "a nasty dog" (255), an "engineered beast" (301) that looks "almost human" (34). As animal, she is victim. Feminist animal rights theorist Carol J. Adams examines gender and the representational politics of meat production in The Sexual Politics of Meat: 
The oppressor then violates this being by object-like treatment: e.g., the rape of women that denies women freedom to say no, or the butchering of animals that converts animals from living breathing beings into dead objects. This process allows fragmentation, or brutal dismemberment, and finally consumption. While the occasional man may literally eat women, we all consume visual images of women all the time.... The consumption of the referent reiterates its annihilation as a subject of importance in itself. (73)

We witness in The Windup Girl an annihilation of Emiko's subjectivity: she is an object that can be dismembered, butchered, used, and consumed. Lake is at first repulsed by the fact that Emiko is genetically engineered but becomes fascinated by her and develops intimate feelings. Even so, he does not hesitate to arrange for Emiko perform sexually for the child queen's regent. She is abused in the power hierarchy because of her genetic profile, and she is isomorphically similar to genetically engineered livestock, genetically docile with marketable flesh. In The Ecological Hoofprint, Tony Weis argues that "[i]n blaming the nature of pigs rather than the nature of production and animal populations, and ostensibly 'fixing' this through genetics, this innovation . . . is a striking new way of representing ecological problems and exerting power over animals" (122). Lake is exerting his power over Emiko, and this representation envisions women as food, ready to be used and consumed.

Women and food are co-located in contemporary media, ${ }^{5}$ and they sometimes serve as accessories to food, as in the case of Japanese "nyotaimori (女体盛り)," which is when sushi and sashimi are served on a naked woman who functions as a plate. In her article "Food, Gender and Representation," Margarita Jankauskait criticizes the representation of women as food in American mass media and advertising, saying that "the feminine body, irksomely related by means of mass media to food products, becomes a product itself. ... Food in Western culture has become an inseparable part of modern feminine identity, taken on unconsciously" (73). Images and representations of women as food and food products are prevalent in the phrases, images, and food advertisements: "to be a woman means to consume, to be consumed and to constantly fight off her extra weight. Therefore to be a woman also means to create using food and food motifs" (Jankauskait 73).

Like food advertisements that contain the images of highly sexual women as food, Emiko seems to be objectified as food. She constantly fears that the Thai military police ("the white shirts") "will mulch" her if they learn of her illegal status as a windup. She is not only a hunted animal but also a piece of meat that can be dismembered, consumed, and discarded. The dehumanization of genetically engineered people highlights the dystopian atmosphere of Bangkok and reveals the conception of women as animals, meat, and food. The humiliated and mutilated Asian woman exposes links between racism, sexism, and speciesism. As ecofeminist Greta Gaard observes, "dominant 
Western culture's devaluation of the erotic parallels its devaluations of women and of nature; in effect, these devaluations are mutually reinforcing" (115). Bacigalupi's dystopian future world is ruled by widespread genetic modification, the dangers of which he warns his readers of. However, his story of possible ecological disaster is tainted by his reproduction of clichéd images from "dominant Western" mass media.

The novel shows the epidemic of plagues that result from random genetic mutations: these plagues threaten both food and people in Bangkok. Every time a disease is conquered by a genetic manipulation, a more toxic mutation develops: "the food web only unravels more completely. Another super-predator won't solve the damage already done" (243). The controversy and the potential danger involving genetically modified food has been much discussed among environmentalists, ecocritics, scientists, farmers, and so on, yet no one is certain of the long-term consequences on humans and the earth. The controversy takes center stage in the novel. When gene engineer Gibbons, "the finest generipper in the world" (61), meets with Kanya, who accuses him of killing people with his GMO products, he argues for their naturalness and inevitability. He says,

Our every tinkering is nature, our every biological striving. We are what we are, and the world is ours. We are its gods. Your only difficulty is your unwillingness to unleash your potential fully upon it.

$[\ldots]$

I advanced my field. It wasn't my business what they did with my research ... I built the tools of life. If people use them for their own ends, then that is their karma, not mine. $(243,245)$

Gibbons argues for GMO's potentials and necessity, yet he does not take responsibility for their disastrous consequence, which sounds almost identical with what happens around the Monsanto corporation. He also speaks for the aggressive Western capitalism that dominates the lives on earth, while covering up the growing uncertainty.

Michael Pollan's experience with Monsanto in his book The Botany of Desire is revealing in this respect. He used genetically modified potato seeds and planted them in his garden. He describes his conversations with potato farmers in Idaho, how they depend on the supplies from Monsanto, and the process of growth of his amazingly fast-growing and bug-free GM potato, "NewLeaf." In Bagiculpi's novel, after genetic engineering, seeds become commodities, and hence "an intellectual property" (Bacigalupi 6), as Lake hears his predecessor Yates saying in the novel. Genetic engineering controls both farmers and nature. 
In some ways, the control over genetic engineering is illusory, and we simply do not know the effects or trajectory of what we are doing. Gene engineers produce sterile seeds ${ }^{6}$ that "no longer do what seeds have always done ... genetic engineers have discovered how to stop on command the most elemental of nature's processes" (Pollan 232). Nevertheless, the problem with this terminator technology is that we do not know how safe it is and whether or not it can jump species. If terminator seeds jump species, we could witness the end of everything. Pollan talked with people from Monsanto and

... was struck by the uncertainty surrounding the process, how this technology is at the same time both astoundingly sophisticated yet still a shot in the genetic dark... This means that the reliability or safety of one genetically modified plant doesn't necessarily guarantee the reliability of safety of the next. (209)

Pollan realizes that even the people at Monsanto are not so certain of how they have produced such seeds, as well as how they will affect the ecosystem, in the long run. "Uncertainty," he explains,

is the theme that unifies most of the questions now being raised about agricultural biotechnology by environmentalist and scientists. We're introducing something novel into the environment and the food chain, the consequences of which are not completely understood. (210, my emphasis)

The novel uses this uncertainty through Emiko's sterile, unstable, imperfect, yet potentially powerful body.

Gibbons, who introduces gene engineering in Thailand, admits this uncertain potential power and danger:

That is the nature of our beasts and plagues. They are not dumb machines to be driven about. They have their own needs and hungers. Their own evolutionary demands. They must mutate and adapt. . . We have released demons upon the world, and your walls are only as good as my intellect. Nature has become something new.... And if our creation devours us, how poetic will that be? (246)

The novel reminds us of the unpredictability of chimerical creations of biotechnology. They are new yet not totally strange, and they look exactly the same as the food we have been eating for thousands of years, just slightly bigger or prettier; yet, they are unpredictable and uncontrollable: "they are chimeras: 'revolutionary' in the patent office and on the farm, 'nothing new' in the supermarket and the environment" (Pollan 189). It is "nothing new" because there is no indication or explanation that it has anything new. The gene engineering corporations are against labeling

Kritika Kultura 33/34 (2019/2020): 577-583 
the ingredients that contain GMOs, and they do not provide the information concerning uncertain effects for nature and human beings, either. Mandatory labeling of GMOs remains one of the most controversial legislation bills in the US. ${ }^{7}$ According to one report,

the totality of scientific research outcomes in the field of GM crop safety is nuanced; complex; often contradictory or inconclusive; confounded by researchers' choices, assumptions, and funding sources; and in general, raised more questions than it has currently answered. (Hilbeck et al.)

As it is, 'genetic instability' is the catch-all term used to describe the various unexpected effects that misplaced or unregulated foreign genes can have on their new environment" (Pollan 208). Tony Weis notes that,

There has been much written about how the spread of GMOs contains many potentials, but as yet unknowable risks for both human health and for ecosystems as new organisms disperse and cross with non-GM crops and wild relatives, and how containment is very difficult. (137)

Both the dangerous ignorance and irresponsible power are well expressed in The Windup Girl: Kanya comes to realize, through Gibbons, that "we are in the hands of a gamesman ... we rest in the hands of a fickle god. He plays on our behalf only for entertainment, and he will close his eyes and sleep if we fail to engage his intellect" (248). The gene engineering in the novel seems to be the work of god but executed by a fickle child; however, this same caveat about the uncertainties and dangers of genetic fiddling, including the human arrogance of "playing god" in the novel, does not reveal the power structure that feeds upon sexism and racism.

Just like freakishly fast-growing GM food with bigger sizes and brighter colors, Emiko turns out to possess unexpected super-human powers. She can move absurdly fast and is freakishly strong when she is pushed beyond a limit:

A windup. Stutter-stop motion and the telltale jerk of a genetically engineered beast. A smart one. And dangerous if pushed, apparently ... viscerally aware that this windup contains the same wild speed of the other one. That all these windups have the potential to become lethal. (301)

In the moment of asserting control, technology opens Pandora's Box. Windup Girls are like Frankenstein's monster in their lethal and unpredictable threats. Emiko's engineered sterility is an attempt to curb the threat of female sexualitylike clitorectomies. Her body takes meaning only to that degree that it suits men's needs. 
Genetically modified seeds are also made sterile so that they cannot mess with the "natural" ecosystem because "the reliability or safety of one genetically modified plant doesn't necessarily guarantee the reliability or safety of the next" (Pollan 209). Emiko, meanwhile, is "a genetic dead end. Doomed to a single life cycle, just like SoyPRO and TotalNutrient Wheat" (114). Emiko has a potential to become lethal and can last longer than the human: she has "perfect eyesight and perfect skin and disease - and cancer-resistant genes ... her hair would never turn gray, and she would never age ..." (34). Even her infertility can be easily changed with Gibbon's gene engineering: "a strand of your hair would do. You cannot be changed, but your children - in genetic terms, if not physical ones - they can be made fertile, a part of the natural world" (358). Gibbons speaks of genetic engineering in mechanical terms, and by simply pushing the button, one can get anything one desires. Selisker explains that "the novel treats genetics like a program that might allow or compel the body to do anything that a computer program might allow a computer to do" (508). The uncanniness of Emiko is accentuated with this familiar vocabulary of computer programming. Like the transformed food that bears both uncertainty and familiarity, she is a mix of the familiar and the unfamiliar, like a human being, but not quite human and a narrative repository of age-old stereotypes of Asia and its women.

Bacigalupi's Bangkok is the $23^{\text {rd }}$ century point on our current trajectory, and we see there the political, social, and ecological problems awaiting us in our dystopian future. The novel highlights the power structure of Western capitalism, which tries to sustain its global domination through the most basic element that humanity needs to survive: food. Despite its critique of Western capitalism and multinational agri-corporations (and the food transformations and uncertainties they produce), The Windup Girl is complicit in reproducing the discourse of imperialism by reiterating racial and gender stereotypes. The problematic representation of Asia and racio-sexist stereotypes overshadows Bacigalupi's otherwise dazzling rendering of food transformations, genetic engineering, and global capitalism. Even with (and perhaps because of) its reification of offensive stereotypes, however, The Windup Girl serves as a warning of some very frightening possibilities that await humanity in the future. 


\section{Notes}

1. The sex industry currently accounts for $3 \%$ of the economy of Thailand. See "Thailand mulls legal prostitution."

2. See Bernard Lewis, Ibn Warraq, Robert Irwin and Denise Porter, for instance.

3. Des Moines, the capital of Iowa. In the novel, this city becomes the power center of the world, where AgriGen controls world seed bank and sends its agents to find new seeds. The protagonist's name, Anderson Lake, also reminds readers of a geographical location called Anderson Lake, better known as Anderson Reservoir, an artificial lake in California. More interestingly, the name has a connotation of phoniness.

4. The stereotypical portrayal of Asians most commonly appears in American mass media, such as popular TV shows like Ally McBeal, The Big Bang Theory, and 2 Broke Girls (Spreedhar).

5. Images of women as food are best exemplified below.

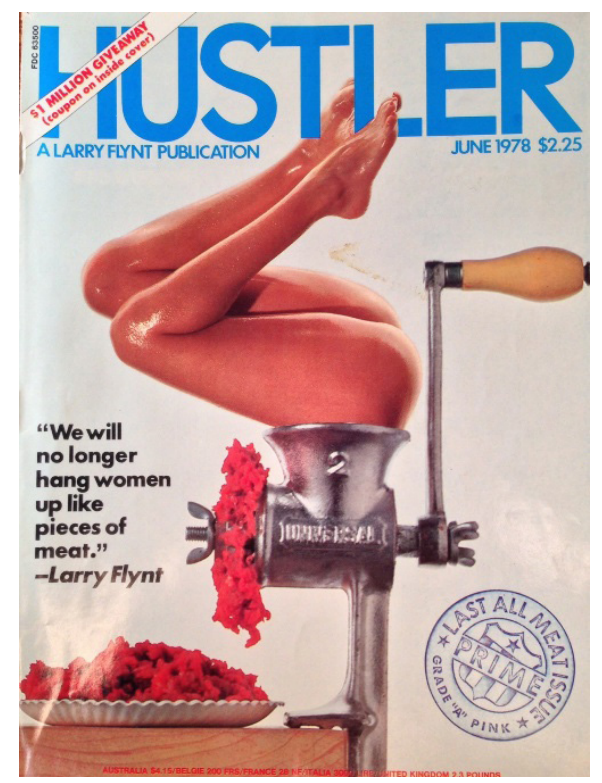

Fig. 1. Gwen Sharp, "The (In)Famous June 1978 Hustler Cover." The Society Pages, thesocietypages. org/socimages/2008/02/29/the-infamous-june-1978-hustler-cover/. 


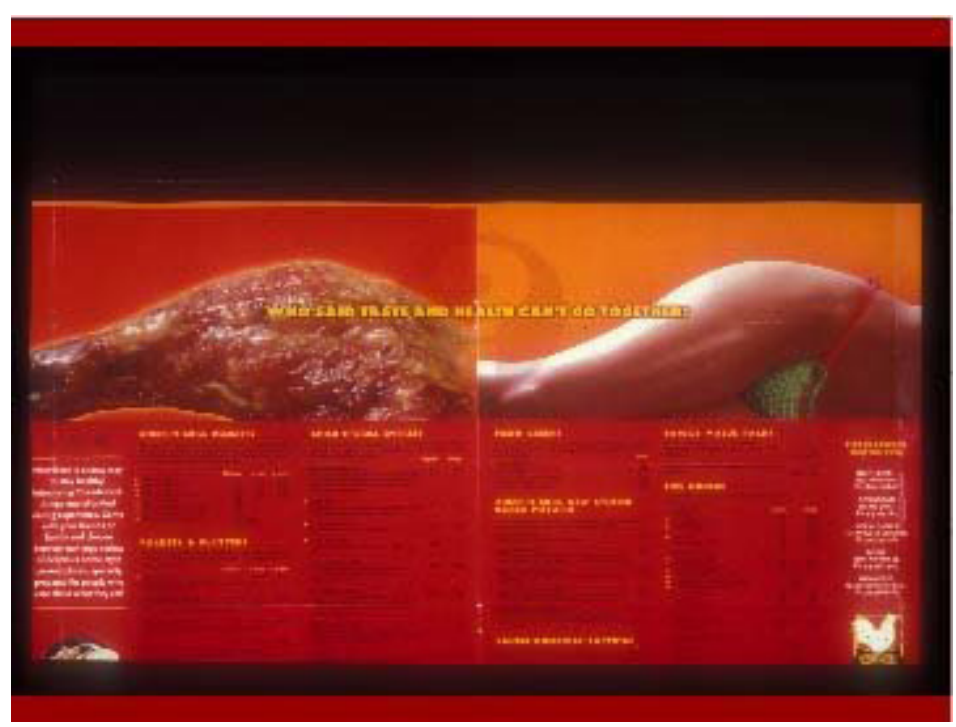

Fig. 2. Gwen Sharp, "Sexy Women as Food." The Society Pages, thesocietypages.org/ socimages/2014/12/19/sexualizing-and-gendering-food/.

6. Terminator Technology: genetic use restriction technology (GURT), also known as suicide seeds, is a new genetic technology that can cause the seeds the plant makes to become sterile. Pollan explains that

With the Terminator, seed companies can enforce their patents biologically and indefinitely. Once these genes are widely introduced, control over the genetics of our crop plants and the trajectory of their evolution will complete its move from the farmer's field to the seed company. (234)

7. Further information can be found at www.nbcnews.com/health/health-news/whygmo-foods-should-be-labeled-n423451;www.huffingtonpost.com/jon-entine/alth ough-some-gmo-sympath_b_8864038.html. 


\section{Works Cited}

Adams, Carol J. The Sexual Politics of Meat. Continuum, 2010.

Akita, Kimiko. "Bloopers of a Geisha: Male Orientalism and Colonization of Women's Language." Women and Language, vol. 32, no. 1, 2006, pp. 12-21.

Bacigalupi, Paolo. The Windup Girl. Night Shade Books, 2012.

Butler, Judith. Gender Trouble: Feminism and the Subversion of Identity. Routledge, 1990.

Davis, Mike. Planet of Slums. Verso, 2017.

Gaard, Greta. "Toward a Queer Ecofeminism." Hypatia, vol. 12, no. 1, 1997, pp. 114-37.

Golden, Arthur. Memoirs of a Geisha. Vintage Books, 1999.

"Gov't to inspect for pesticides before HACCP certification." Yonhap News, 8 Sept. 2017, english.yonhapnews.co.kr/search1/260300oooo.html?cid=AEN20170921004500320. Accessed 7 Dec. 2017.

Hageman, Andrew. "The Challenge of Imagining Ecological Futures: Paolo Bacigalupi's The Windup Girl." Science Fiction Studies, vol. 39, 2012, pp. 283-303.

Haraway, Donna. Simians, Cyborgs and Women: Reinvention of Nature. Routledge, 1991.

Hilbeck, Angelica, Rosa Binimelis, Nicolas Defarge, Ricarda Steinbrecher, András Székács, Fern Wickson, Michael Antoniou, Philip L Bereano, Ethel Ann Clark, Michael Hansen, Eva Novotny, Jack Heinemann, Hartmut Meyer, Vandana Shiva, and Brian Wynne. "No Scientific Consensus on GMO Safety." Environmental Science Europe, vol. 27, no. 4, 2015. Springer Link, enveurope.springeropen.com/articles/10.1186/s12302-014-0034-1.

Irwin, Robert. For Lust of Knowing: The Orientalists and their Enemies. Allen Lane, 2006.

Jankauskait, Margarita. "Food, Gender and Representation." Anthropology of East Europe Review, vol. 21, 2003, pp. 73-76.

Kang, Susan. "Irrationality and Regulation: Constructing Mad Cow Knowledge in the USSouth Korea FTA." Globalizations, vol. 10, no. 4, 2013, pp. 587-601,

Kingsolver, Barbara. Animal, Vegetable, Miracle: A Year of Food Life. Harper Collins, 2007.

Kawaguchi, Yoko. Butterfly's Sisters: The Geisha in Western Culture. Yale UP, 2010.

Kurtz, Malisa. "A Dis-(Orient)ation Race, Technoscience, and The Windup Girl." Black and Brown Planets: The Politics of Race in Science Fiction, edited by Isiah Lavender III, UP of Mississippi, 2014, pp. 177-94.

Lewis, Bernard. "The Question of Orientalism." New York Review of Books, vol. 29, no. 11, 1982, pp. 1-20.

Morton, Timothy. The Ecological Thought. Harvard UP, 2010.

Pickering, Michael. Stereotyping: The Politics of Representation. Palgrave, 2001.

Pollan, Michael. The Botany of Desire. Random House, 2001.

Porter, Dennis. "Orientalism and its Problems." The Politics of Theory, edited by Francis Barker, University of Essex, 1983, pp. 179-93.

Said, Edward. Orientalism. Vintage Books, 1994.

Selisker, Scott. "Stutter-Stop Flash-Bulb Strange': GMOs and the Aesthetics of Scale in Paolo Bacigalupi's The Windup Girl." Science Fiction Studies, vol. 42, 2015, pp. 500-18. 
Sharp, Gwen. "Sexy Woman as Meat." The Society Pages, 19 Dec. 2014, thesocietypages.org/ socimages/2014/12/19/sexualizing-and-gendering-food/. Accessed 7 Dec. 2017.

--. "The (In)Famous June 1978 Hustler Cover." The Society Pages, 29 Feb. 2008, thesocietypages.org/socimages/2008/02/29/the-infamous-june-1978-hustler-cover/. Accessed 7 Dec. 2017.

Spreedhar, Anjana. "5 most offensive Asian characters in TV history." Salon. Com, 23 Sept. 2013, salon.com/2013/09/22/tvs_5_most_offensive_asian_characters_partner/. Accessed 7 Dec. 2017.

Suleri, Sara. The Rhetoric of English India. U of Chicago P, 1992.

"Thailand mulls legal prostitution." The Age, 26 Nov. 2003, www.theage.com.au/ articles/2003/11/26/1069825832486.html?oneclick=true. Accessed 7 Dec. 2017.

Ussher, Jane M. Fantasies of Femininity: Reframing the Boundaries of Sex. Rutgers UP, 1997.

Warraq, Ibn. Defending the West: A Critique of Edward Said's Orientalism, Prometheus Books, 2007.

Weis, Tony. The Ecological Hoofprint: The Global Burden of Industrial Livestock. Zed Books, 2013.

Welford, Win. "Supermarket Semantic: The Rhetoric of Food Labeling and Advertising." ETC: A Review of General Semantics, vol. 49, no.1, 1992, pp. 3-17. 